Gut, 1986, 27, 1186-1192

Liver and biliary

\title{
Tumours and pseudotumours of the region of the ampulla of Vater: an endoscopic, clinical and pathological study
}

\author{
T LEESE, J P NEOPTOLEMOS, K P WEST, I C TALBOT, AND D L CARR-LOCKE
}

From the Departments of Surgery, Pathology and Gastroenterology, University of Leicester, Leicester

SUMMARY From a large series of patients referred for endoscopic retrograde cholangiopancreatography to one endoscopist, 49 patients had the duodenoscopic appearance of a periampullary tumour. Thirty eight of these lesions were neoplastic, but the remaining 11 patients had inflammatory non-neoplastic lesions (pseudotumours). These could not be distinguished from the neoplasms on endoscopic appearances. The cholangiopancreatograms were similar except that the diameter of the pancreatic duct tended to be higher in the tumour group and gall stones were present significantly more often in the patients with pseudotumour. Endoscopic biopsy correctly diagnosed 28 of 34 ampullary carcinomas. Two of the 11 pseudotumour patients were subjected to surgical excision biopsy because of suspicious histological features of endoscopic biopsy. In the neoplastic group 19 patients underwent Whipple's procedure, seven surgical bypass, seven endoscopic sphincterotomy only and five died without successful biliary drainage. The overall one year survival was $44.7 \%$. By contrast, the patients with pseudotumours were clinically well at a median follow up 24 months (range 12-41 months), after endoscopic sphincterotomy except for one 89 year old patient who died 22 months later from unrelated causes.

The incidence of carcinoma of the pancreas appears to be rising in the industrialised nations, with a proportional increase in periampullary cancers. ${ }^{1}$ Part of the increase in this incidence is related to improvements in diagnostic techniques, particularly endoscopic retrograde cholangiopancreatography (ERCP), ultrasonography and computed tomography scanning. ${ }^{2}$ Tumours of the periampullary region are neoplastic lesions involving the ampulla of Vater arising from the duodenum and lower common bile duct as well as from the ampulla. ${ }^{2-5}$ It is often difficult to distinguish between these tumours and those which may arise from the distal duct of Wirsung and the glandular tissue at the head of the pancreas when these invade into the ampullary region and penetrate the duodenal mucosa. ${ }^{34}$ Although duodenoscopy and ERCP have revolutionised the pre-operative diagnosis of these tumours considerable difficulties occur in differ-

Address for correspondence: Mr T Leese, FRCS. Department of Surgery, Clinical Sciences Building. Leicester Royal Infirmary. PO Box 65, Leicester LE2 7LX.

Received for publication 27 January 1986 entiating between benign and malignant lesions before surgery. ${ }^{5-8}$ Early and accurate diagnosis is important for those patients with malignant periampullary lesions as the prognosis is generally much more favourable than from pancreatic cancer after radical resection. ${ }^{8-15}$ The role of duodenoscopic biopsy for diagnosing periampullary lesions has, however, not been widely evaluated. This report details the results of 49 patients who presented with periampullary tumours, 11 of whom had inflammatory non-neoplastic lesions.

\section{Methods}

PATIENTS

Between January 1975 and December 1983, over 2000 patients in the Leicestershire area were referred for ERCP to DLC-L, of whom 49 had the appearances of a periampullary carcinoma on duodenoscopy, the commonest appearance of which is a proliferative swelling at the papilla with a central depression which may be ulcerated. In the opinion of the endoscopist these would all have been classified macroscopically as malignant tumours, 
obviously inflammatory lesions are not included in this study.

Biopsies were taken endoscopically both before and after endoscopic sphincterotomy and an ERCP attempted through the tumour mass. Cytology was not used in this study. Thirty eight patients had neoplastic lesions, but 11 patients had nonneoplastic lesions despite the duodenoscopic appearances. The clinical, biochemical, and haematological features were reviewed, along with the findings at ERCP, surgery, and necropsy. All patients had been followed up for a minimum period of one year. The biopsy specimens were independently reviewed by a pathologist (KPW).

The Mann-Whitney ranking test was used to analyse continuous parameters (Minitab Computer package). The $\chi^{2}$ test with Yates correction and the two tailed Fishers exact probability test were used to analyse clinical variables between the two groups.

\section{Results}

\section{CLINICAL FEATURES}

A comparison between the two groups is shown in Table 1. There was no difference statistically be-

Table 1 Comparison of clinical findings

\begin{tabular}{|c|c|c|}
\hline & Tumours & $\begin{array}{l}\text { Pseudo- } \\
\text { tumours }\end{array}$ \\
\hline $\mathbf{N}$ & 38 & 11 \\
\hline Females & $21(55 \cdot 3 \%)$ & $6(54 \cdot 5 \%)$ \\
\hline $\begin{array}{l}\text { Age } M \pm S D \text { years } \\
\text { (range) }\end{array}$ & $\begin{array}{l}65 \cdot 4 \pm 21 \cdot 4 \\
(30-91)\end{array}$ & $\begin{array}{l}70 \cdot 8 \pm 16 \cdot 9 \\
(33-88)\end{array}$ \\
\hline \multicolumn{3}{|l|}{ History } \\
\hline Abdominal pain & $16(42 \%)$ & $9(81 \cdot 8 \%)$ \\
\hline Epigastric pain & $7(18.4 \%)$ & $7(63.6 \%)$ \\
\hline Right hypochondrial pain & $8(21 \cdot 1 \%)$ & $2(18 \cdot 2 \%)$ \\
\hline Back pain & $1(2 \cdot 6 \%)$ & $0(0 \%)$ \\
\hline Jaundice & $33(86.8 \%)$ & $8(72 \%)$ \\
\hline Pruritus & $20(52 \cdot 6 \%)$ & $3(27 \cdot 3 \%)$ \\
\hline Anorexia & $22(57.9 \%)$ & $11(100 \%)$ \\
\hline Weight loss & $24(63 \cdot 1 \%)$ & $10(90.9 \%)$ \\
\hline Amount of weight loss & $16 \cdot 9 \pm 24 \cdot 9$ & $23 \cdot 5 \pm 17 \cdot 1$ \\
\hline $\mathrm{M} \pm \mathrm{SD}$ lb (range) & $(0-123)$ & $(0-46)$ \\
\hline Nausea & $14(34.8 \%)$ & $7(63 \cdot 6 \%)$ \\
\hline Vomiting & $12(31 \cdot 6 \%)$ & $8(72 \cdot 7 \%)$ \\
\hline Palc stool & $28(73.7 \%)$ & $6(54 \cdot 5 \%)$ \\
\hline Dark urine & $29(76 \cdot 3 \%)$ & $6(54 \cdot 5 \%)$ \\
\hline Rigors & $11(28.9 \%)$ & $3(27 \cdot 3 \%)$ \\
\hline Gastrointestinal blecding & $2(5 \cdot 3 \%)$ & $0(0 \%)$ \\
\hline Length of history & $6 \cdot 8 \pm 6 \cdot 7$ & $11 \cdot 1 \pm 14 \cdot 2$ \\
\hline $\mathrm{M} \pm \mathrm{SD}$ weeks (range) & $(1-24)$ & $(1-52)$ \\
\hline \multicolumn{3}{|l|}{ Clinical examination } \\
\hline Jaundice & $33(86 \cdot 8 \%)$ & $8(72 \cdot 7 \%)$ \\
\hline Hepatomegaly & $26(68 \cdot 4 \%)$ & $3(27 \cdot 3 \%)$ \\
\hline Palpable gall bladder & $16(42 \cdot 1 \%)$ & $0(0 \%)$ \\
\hline Cholangitis & $6(15 \cdot 8 \%)$ & $1(0.9 \%)$ \\
\hline
\end{tabular}

tween either group in any of the features recorded with the exception that in patients with pseudotumours there was a higher proportion with epigastric pain (Fishers exact probability test, $\mathrm{p}<0 \cdot 01$ ). With respect to abdominal pain in general, however, there was no difference between the two groups. One patient with a pseudotumour had acute cholangitis (blood culture positive for $E$ coli). Six patients with ampullary tumours had clinical cholangitis (abdominal pain, rigors, pyrexia $>38^{\circ} \mathrm{C}$ and jaundice). Of these three had positive blood cultures (Strep faecalis and Strep pneumonia; Klebsiella; Ps aerunginosa, respectively) and in a fourth frank pus was seen after endoscopic sphincterotomy. No patients with pseudotumours had a palpable gall bladder on examination whereas $16 \quad(42.1 \%)$ patients with ampullary tumours had a palpable gall bladder.

HAEMATOLOGICAL AND BIOCHEMICAL VARIABLES These are summarised in Table 2. Lower values of haemoglobin, haematocrit, total protein and albumin were found in the tumour group than in the pseudotumour group. One patient in the latter group had low albumin and total protein levels -

Table 2 Comparison of haematological and biochemical tests

\begin{tabular}{|c|c|c|c|}
\hline & $\begin{array}{l}\text { Tumours } \\
(n=38) \\
M \pm S D \\
\text { (range) }\end{array}$ & $\begin{array}{l}\text { Pseudo- } \\
\text { tumours } \\
(n=I I) \\
M \pm S D \\
\text { (range) }\end{array}$ & \\
\hline Haemoglobin $(\mathrm{g} / \mathrm{l})$ & $\begin{array}{l}11 \cdot 53 \pm 1 \cdot 72 \\
(7 \cdot 8-14 \cdot 5)\end{array}$ & $\begin{array}{l}13 \cdot 61 \pm 1 \cdot 96 \\
(11 \cdot 3-17 \cdot 9)\end{array}$ & $\mathrm{p}<0.003$ \\
\hline Haematocrit (\%) & $\begin{array}{l}35 \pm 5 \cdot 09 \\
(24 \cdot 9-43 \cdot 1)\end{array}$ & $\begin{array}{l}40 \cdot 92 \pm 5 \cdot 91 \\
(35 \cdot 8-54 \cdot 8)\end{array}$ & $\mathrm{p}<0.016$ \\
\hline $\begin{array}{l}\text { White cell count } \\
\qquad\left(\times 10^{9} / 1\right)\end{array}$ & $\begin{array}{l}9 \cdot 37 \pm 4 \cdot 63 \\
(4 \cdot 3-23 \cdot 2)\end{array}$ & $\begin{array}{l}9.01 \pm 3.68 \\
(5 \cdot 2-18 \cdot 8)\end{array}$ & NS \\
\hline Urea (mmol/l) & $\begin{array}{l}8 \cdot 36 \pm 9 \cdot 36 \\
(2 \cdot 8-45 \cdot 1)\end{array}$ & $\begin{array}{l}5 \cdot 88 \pm 2 \cdot 32 \\
(3 \cdot 2-12 \cdot 1)\end{array}$ & NS \\
\hline Creatinine $(\mu \mathrm{mol} / \mathrm{l})$ & $\begin{array}{l}141 \cdot 5 \pm 168 \cdot 7 \\
(32-782)\end{array}$ & $\begin{array}{l}102 \cdot 7 \pm 22 \cdot 8 \\
(72-138)\end{array}$ & NS \\
\hline Total protein $(\mathrm{g} / \mathrm{l})$ & $\begin{array}{l}62 \cdot 17 \pm 6 \cdot 49 \\
(51-82)\end{array}$ & $\begin{array}{l}67 \pm 5 \cdot 31 \\
(54-72)\end{array}$ & $\mathrm{p}<0 \cdot 01$ \\
\hline Albumin $(\mathrm{g} / \mathrm{l})$ & $\begin{array}{l}31 \cdot 93 \pm 5 \cdot 52 \\
(20-41)\end{array}$ & $\begin{array}{l}36 \cdot 8 \pm 3 \cdot 71 \\
(28-42)\end{array}$ & $\mathrm{p}<0 \cdot 016$ \\
\hline $\begin{array}{l}\text { Alkaline phosphatase } \\
\text { (IU/I) }\end{array}$ & $\begin{array}{l}819 \pm 573 \\
(67-2862)\end{array}$ & $\begin{array}{l}571 \pm 345 \\
(256-1220)\end{array}$ & NS \\
\hline $\begin{array}{c}\gamma \text {-Glutamyl (IU/I) } \\
\text { transpeptidase }\end{array}$ & $\begin{array}{l}442 \pm 394 \\
(14-15(0))\end{array}$ & $\begin{array}{l}497 \pm 300 \\
(173-1113)\end{array}$ & NS \\
\hline $\begin{array}{l}\text { Alanine transaminase } \\
\text { (IU/l) }\end{array}$ & $\begin{array}{l}145 \pm 115 \\
(9-525)\end{array}$ & $\begin{array}{l}279 \pm 238 \\
(25-885)\end{array}$ & $\mathrm{p}<0 \cdot 03$ \\
\hline Bilirubin $(\mu \mathrm{mol} / \mathrm{l})$ & $\begin{array}{l}189 \pm 159 \\
(6-663)\end{array}$ & $\begin{array}{l}106 \cdot 5 \pm 79 \cdot 6 \\
(37-314)\end{array}$ & NS \\
\hline
\end{tabular}

Mann Whitney Ranking Test 
this patient has had repeat endoscopy and follow up of more than 22 months and remains well. All the other patients had normal albumin and total protein concentrations and none of the 11 patients had a low haematocrit or a haemoglobin of $<11.3 \mathrm{~g} / \mathrm{l}$. In comparison only 14 of the 38 patients with tumours had normal concentrations of haemoglobin, haematocrit, albumin, and total protein $(36 \cdot 8 \%)$.

There was no difference with respect to serum bilirubin and liver enzymes except that patients with pseudotumours tended to have higher concentrations of alanine transaminase.

FINDINGS AT ERCP

The success rate of cannulating the pancreatic and common bile ducts and their diameters are shown in Table 3. Although the diameter of the pancreatic ducts tended to be higher in tumour group there was no difference with respect to common bile duct diameters to the pseudotumour group and the



Fig. 1 Endoscopic retrograde cholangiograms in a case endoscopic retrograde cholangiograms looked similar in many cases (Fig. 1). Gall stones were present significantly more so in the pseudotumour group (Table 3 ). The nine patients in the pseudotumour group who had not previously undergone cholecystectomy also had ultrasonography and the findings corroborated the presence or absence of stones in the gall bladder.

\section{PATHOLOGY}

\section{Tumours}

Thirty eight neoplasms involving the region of the ampulla of Vater were identified in this series. Thirty four of these were carcinomas, one a malignant lymphoma, one an endocrine tumour probably of enterochromaffin origin, and two tubulovillous adenomas.

Sections of 33 of the carcinomas were available for review, in the remaining case the presence of an ampullary carcinoma was confirmed at necropsy. In

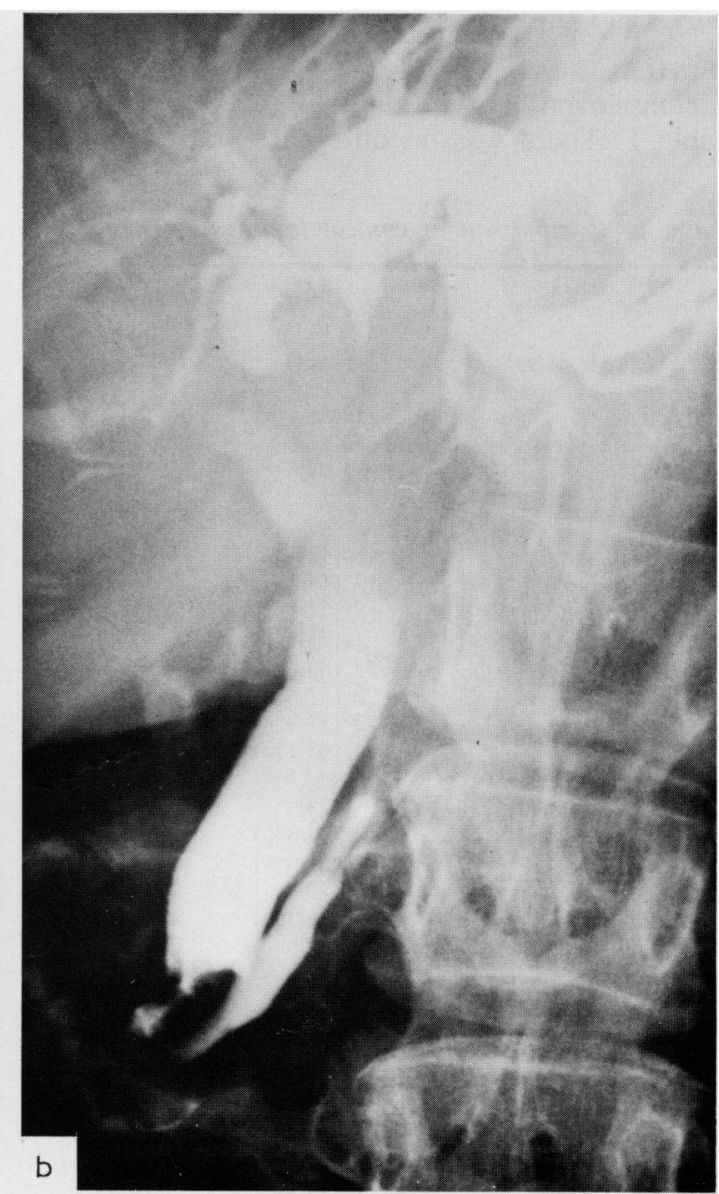

of pseudotumour (a) and periampullary carcinoma (b). 
28 cases adenocarcinoma was present in the initial endoscopic biopsy. Five biopsies did not reveal definitive evidence of malignancy but at subsequent

Table 3 Comparison of the results of ERCP

\begin{tabular}{|c|c|c|c|}
\hline & $\begin{array}{l}\text { Tumours } \\
(n=38)\end{array}$ & $\begin{array}{l}\text { Pseudotumours } \\
(n=I I)\end{array}$ & \\
\hline Successful ERC & $31(82 \%)$ & $11(100 \%)$ & \\
\hline Diameter $\mathrm{CBD}(\mathrm{mm})$ & & & \\
\hline $\begin{array}{l}\text { Mean } \pm S D \\
\text { (range) }\end{array}$ & $\begin{array}{l}17 \cdot 35 \pm 5 \cdot 71 \\
(8-35)\end{array}$ & $\begin{array}{l}16 \pm 3 \cdot 61 \\
(10-20)\end{array}$ & NS \\
\hline Successful ERP & $28(74 \%)$ & $10(91 \%)$ & \\
\hline $\begin{array}{l}\text { Diameter PD }(\mathrm{mm}) \\
\text { Mcan } \pm S D \\
\text { (range) }\end{array}$ & $\begin{array}{l}6 \cdot 86 \pm 2 \cdot 55 \\
(2-13)\end{array}$ & $\begin{array}{l}4 \cdot 8 \pm 1 \cdot 87 \\
(3-9)\end{array}$ & $p=0 .(1) 2$ \\
\hline $\begin{array}{l}\text { Previous } \\
\text { cholecystectomy }\end{array}$ & $1(2 \cdot 6 \%)$ & $2(18 \cdot 1 \%)$ & NS \\
\hline Gall stones present & $7(18.4 \%)$ & $6(54.5 \%)$ & $\mathrm{tp}<0 \cdot(0) 2$ \\
\hline Gall bladder & $4(10 \cdot 5 \%)$ & $4(36 \cdot 3 \%)$ & \\
\hline Common bile duct & $1(2 \cdot 6 \%)$ & $1(9 \cdot 1 \%)$ & \\
\hline $\begin{array}{l}\text { Gall bladder } \\
\text { and common } \\
\text { bilc duct }\end{array}$ & $2(5 \cdot 3 \%)$ & $1(9.1 \%)$ & \\
\hline
\end{tabular}

Mann Whitney Ranking Test

$t \chi^{2}$ Test with Yates Correction



laparotomy carcinomas were identified in all five cases on frozen section examination of the papilla.

Histological grading of the carcinomas revealed that 14 were well differentiated, 10 moderately differentiated and four poorly differentiated. Twelve of the lesions were papillary in configuration (Fig. 2). These results are similar to those of a previous study of periampullary carcinomas. ${ }^{+}$

The two tubulovillous adenomas identified were similar to their counterparts in the large intestine. Both exhibited severe epithelial dysplasia. There was no evidence of invasion on the biopsies, but one was shown to have carcinoma in situ on the resected specimen.

The single endocrine tumour in this study infiltrated the duodenal wall in the region of the ampulla of Vater. It was also adjacent to a nodule of ectopic pancreatic tissue. Although its appearances were consistent with a tumour of enterochromaffin origin, an origin from ectopic pancreas could not be completely excluded. No abnormal serum peptide concentrations were found.

\section{Pseudotumours}

Sections of 10 of the 11 cases of pseudotumour were

Fig. 2 Histological appearance of (a) An ampullary pseudotumour ( $H$ and $E$ ), (b) A papillary carcinoma of the ampulla of Vater ( $H$ and $E$ ).

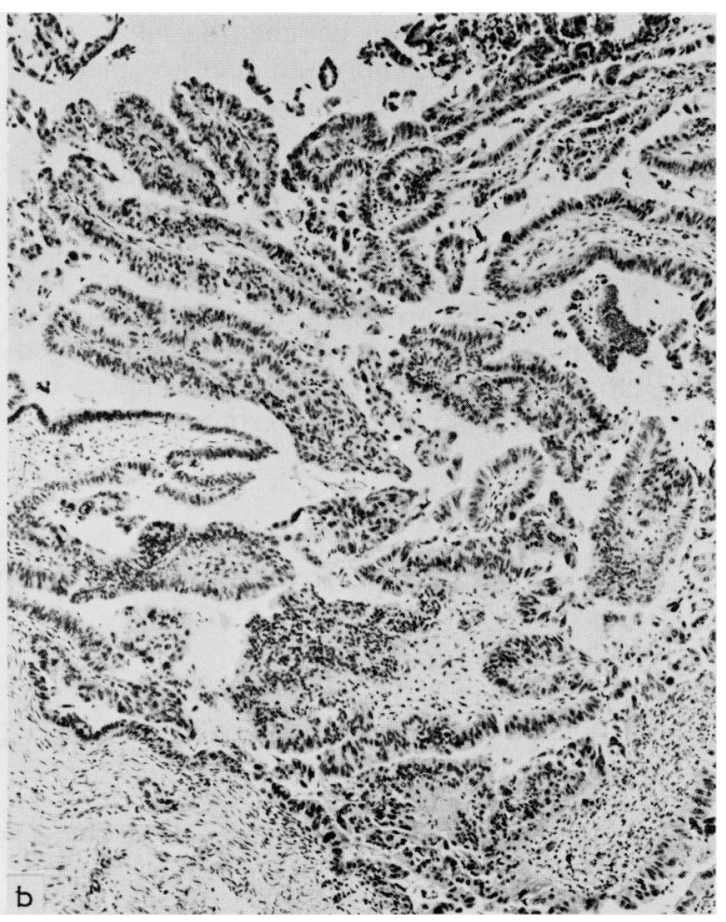


available for review. Nine of the 10 biopsies consisted of small fragments of duodenal mucosa with a variable mixed inflammatory cell infiltrate in the lamina propria (Fig 2). This infiltrate included neutrophil polymorphs, lymphocytes, plasma cells, and histiocytes. The other biopsy consisted of duodenal mucosa and submucosa, the latter containing a nodule of ectopic pancreatic tissue. There was no evidence of malignancy in any of these biopsies.

\section{CLINICAL OUTCOME}

\section{Tumours}

The treatment of the 38 patients with periampullary neoplasia is summarised in Figure 3. Nineteen underwent Whipple's procedure with three deaths within 30 days of surgery $(15 \cdot 8 \%)$ and overall survival at one and three years of $73.6 \%$ and $60 \%$ respectively. At the time of follow up 12 of these patients are still alive and the longest survivor is well after 10 years.

Seven patients underwent surgical bypass, two of these being late bypasses for duodenal obstruction after initial endoscopic sphincterotomy had decompressed the biliary tree. Three of these patients died within 30 days of surgery $(43 \%)$ and the mean survival was eight months (range 0-38 months).

In 20 patients endoscopic sphincterotomy was attempted through the periampullary tumour to relieve jaundice. In seven patients the biliary tree was successfully decompressed before planned laparotomy (six Whipple's procedures, one surgical bypass). The other 13 patients with positive biopsies were thought unfit for major surgery and endoscopic sphincterotomy was intended as the only treatment: this was successful in nine but two patients required late surgical bypass for duodenal obstruction. The mean survival in this group was nine months (range 2-17 months). In the remaining four patients (aged $71,73,87$, and 91 years) attempts to decompress the biliary tree at endoscopic sphincterotomy failed and surgery was not attempted. These patients all died within 30 days.

One 30 year old man died soon after admission from cholangitis leading to septicaemia and hepatorenal failure before biliary decompression was attempted.

\section{Pseudotumours}

The duodenoscopic appearances of all these tumours was identical to the non-ulcerating papilliferous type adenocarcinoma of the ampulla of Vater. Although many of them only had an inflammatory appearance on histology the features were sufficiently disturbing for two patients to have a laparotomy. In both cases a duodenotomy was carried out and the ampulla was resected for frozen section biopsy. These specimens showed no evidence of neoplasia on either frozen section or paraffin section histology. The remaining nine patients with pseudotumours had endoscopic sphincterotomy to decompress the biliary tree and in two cases allow extraction of stones from the common bile duct.

The median follow up of these patients was 24 months (range 12-41 months). One patient aged 83 years at presentation died 22 months later from unrelated causes. This and the other 10 patients remained clinically well after endoscopic sphincterotomy. Seven of the patients had had repeat ERCP and biopsy indicating resolution of the pseudotumours at between three and 24 months.

\section{Discussion}

This study has shown the difficulties which can occur in attempting to make a pre-operative diagnosis of an ampullary tumour. Although the majority of neoplastic lesions were adequately confirmed by endoscopic biopsy in five cases the correct diagnosis was not made until laparotomy. Three of the

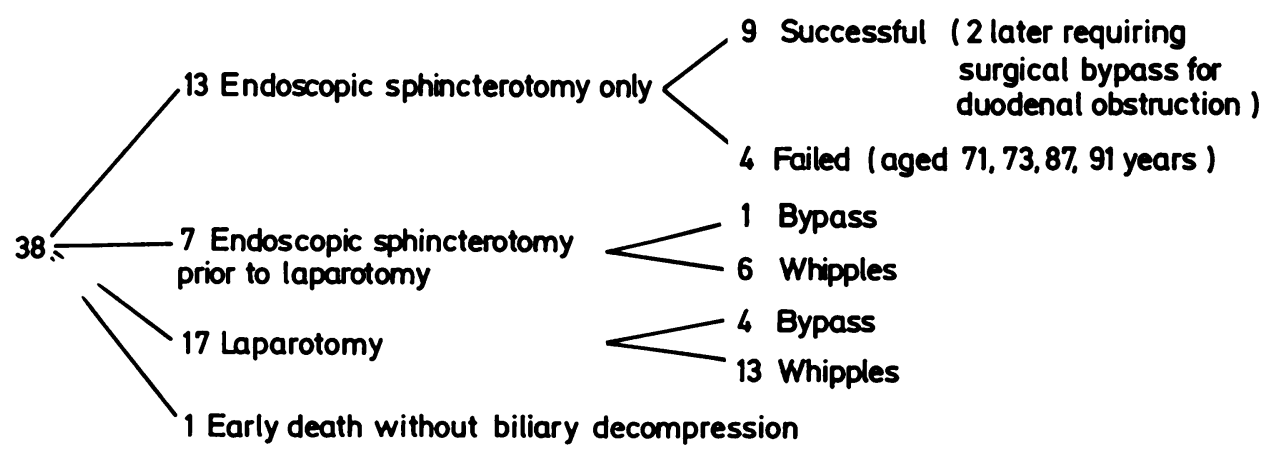

Fig. 3 Clinical outcome in 38 patients with periampullary neoplasms. 
patients had a benign neoplastic lesion. Benign tumours of the ampulla of Vater include leiomyofibromas, lipomas, neurogenic tumours, haemangiomas and carcinoid tumours. 51627 The commonest benign neoplastic lesion is the villous adenoma. ${ }^{17-19} \mathrm{Up}$ to $30 \%$ of cases show evidence of in situ or invasive malignant changes, and was present in one of the two cases in the present series. ${ }^{17} 19$ The third patient with a benign neoplastic lesion had a non-secreting endocrine tumour which may have originated in ectopic pancreatic tissue.

Eleven of 49 patients had a non-neoplastic periampullary tumour which we have described as a pseudotumour. The clinical history, clinical examination and the haematological and biochemical data showed a considerable overlap between the patients with tumours and those with pseudotumours. Helpful differences were that no patients with pseudotumours had a palpable gall bladder whereas $42 \%$ of patients with ampullary tumours had a positive Courvoisiers law. Also all the patients with pseudotumours had a haemoglobin $>11.3 \mathrm{~g} / \mathrm{l}$ and normal haematocrit levels. The duodenoscopic appearances were similar in both groups and both groups had similarly dilated common bile ducts. The pancreatic ducts were more dilated in the tumour group, but this feature would only be helpful in a few patients. Six of 11 pseudotumour patients had gall stones at the time of ERCP although they were present in the common bile duct in only two cases, and two further patients had undergone previous cholecystectomy (18 months and four years earlier). This suggests that one aetiological factor may be the passage of calculi through the ampulla of Vater resulting in inflammatory changes with pseudotumour formation. In 1938 Baggenstoss reported 18 cases of adenomatous hyperplasia in 100 consecutive necropsy cases. ${ }^{20}$ Baggenstoss noted the similarity between polyps, adenomatoid hyperplasia, and low grade papillary carcinoma of the papilla of Vater. The hypothesis was advanced that because the papilla is an area of epithelial transition local irritation of the mucosa of the papilla (by enzymes and bile salts) plays an important part in the development of polypoid hyperplasia. ${ }^{20}$ Further follow up of our cases in this series may indicate to what extent this hypothesis is correct.

It may be possible to improve the accuracy of diagnosing a malignant lesion by repeating the endoscopic biopsy several days after an endoscopic sphincterotomy. ${ }^{7}$ In the light of our observations it would seem wise to recommend the following management policy. Whenever an ampullary 'tumour' is found endoscopic biopsy and sphincterotomy should be carried out. If doubt about the malignant nature of the lesion persists then the area should be re-examined, with repeat biopsies, after an interval to allow resolution of any inflammatory reaction in the peri-ampullary tissues. If doubt still exists then intraoperative frozen section examination of a periampullary biopsy is indicated before proceeding to radical surgery.

The policy has been adhered to in 12 patients presenting with the duodenoscopic appearance of a periampullary carcinoma since completion of this study. Nine patients had initial endoscopic biopsies confirming periampullary carcinoma, but in three the biopsies were reported as benign and repeat ERCP and biopsy confirmed the benign nature of the lesions which resolved under duodenoscopic surveillance.

\section{References}

1 Levin DL, Connelly RR, Devesa SS. Demographic characteristics of cancer of the pancreas: mortality, incidence and survival. Cancer 1981; 47: 1456-68.

2 Cooperman AM. Cancer of the ampulla of Vater, bile duct, and duodenum. Surg Clin $N A m$ 1981; 61: 99-106.

3 Miller EM, Dockerty MB, Wollaeger EE, Waugh JM. Carcinoma in the region of the papilla of Vater. A study of cases in which resection was performed. Surg Gynecol Obstet 1951; 92: 172-82.

4 Blumgart LH, Kennedy A. Carcinoma of the ampulla of Vater and duodenum. Br J Surg 1973; 60: 33-40.

5 Venables CW. The papilla and malignancy: Problems in clinical practice. In Salmon PR, ed. Gastrointestinal endoscopy. Advances in diagnosis and therapy. Vol. 1. London: Chapman and Hall, 1984: 207-18.

6 Gouerou H, Mendez J, Crespon B, Berman H, Houset P, Debray C. La duodenoscopie dans le diagnostie des ampullomes Vate - riens. Arch Fr Mal App Dig 1976; 65: 569-75.

7 Bourgeois N, Dunham F, Verhest A, Cremer M. Endoscopc biopsies of the papilla of Vater at the time of endoscopic sphincterotomy: difficulties in interpretation. Gastrointest Endosc 1984; 30: 163-6.

8 Walsh DB, Eckhauser FE, Cronenwett JL, Turcotte JG, Lindenauer SM. Adenocarcinoma of the ampulla of Vater. Diagnosis and treatment. Ann Surg 1982; 195: $152-7$.

9 Smith R. The surgeon and the patient with cancer. $J R$ Coll Surg Edinb 1970; 15: 63-76.

10 Warren KW, Choe DS, Plaza J, Relihan M. Results of radical resection for periampullary cancer. Ann Surg 1975; 181: 534-9.

11 Wise L, Pizzimbono C. Dehner LP. Periampullary cancer: A clinicopathologic study of sixty-two patients. Am J Surg 1976; 131: 141-7.

12 Coutsoftides T, Macdonald J, Shibata HR. Carcinoma of the pancreas and periampullary region: a 41 year experience. Ann Surg 1977; 186: 730-3.

13 Schlippert W, Lucke D, Anuras S, Christensen J. Carcinoma of the papilla of Vater. A review of fifty-seven cases. Am J Surg 1978; 135: 763-70. 
14 Forrest JF, Longmire WP. Carcinoma of the pancreas and periampullary region. A study of 279 patients. Ann Surg 1979; 189: 129-38.

15 Obertop H, Bruining HA, Eeftinck Schattenkerk M, Eggink WF, Jeekel J, Van Houten H. Operative approach to cancer of the head of the pancreas and the periampullary region. $B r J$ Surg 1982; 69: 573-6.

16 Curry B, Gray N. Visceral neurofibromatosis. An unusual cause of obstructive jaundice. Br J Surg 1972; 59: $494-6$.
17 Denjoy R. Les tumeurs benignes de la papille de Vater. J Chir (Paris) 1968; 95: 211-26.

18 Sobol S, Cooperman AM. Villous adenoma of the ampulla of Vater: An unusual cause of biliary colic and obstructive jaundice. Gastroenterology 1978; 75: 107-9.

19 Schulten MF, Oyasu R, Beal JM. Villous adenoma of the duodenum. A case report and review of the literature. Am J Surg 1976; 132: 90-6.

20 Baggenstoss AH. Major duodenal papilla: variations of pathologic interest and lesions of mucosa. Arch Pathol 1938; 26: 853-68. 